\title{
Photodynamic Activity of Chloro(5,10,15,20-tetraphenylporphyrinato)indium(III)
}

\author{
André R. da Silva, ${ }^{a}$ Alessandra C. Pelegrino, ${ }^{b}$ Antonio C. Tedesco ${ }^{b}$ and Renato A. Jorge ${ }^{*, a}$ \\ ${ }^{a}$ Departamento de Físico-Química, Instituto de Química, Universidade Estadual de Campinas, \\ CP 6154, 13084-971 Campinas-SP, Brazil \\ ${ }^{b}$ Departamento de Química, Faculdade de Filosofia Ciências e Letras, Universidade de São Paulo, \\ 14040-901 Ribeirão Preto-SP, Brazil
}

\begin{abstract}
A atividade fotodinâmica do cloro(5,10,15,20-tetrafenilporfirinato) de índio(III) (InTPP) in vitro foi investigado para possível uso em terapia fotodinâmica (PDT). O rendimento quântico de oxigênio singlete do InTPP $\left(\Phi_{\Delta}=0,72\right)$ em DMSO foi maior que da 5,10,15,20-tetrafenilporfirina (TPP) $\left(\Phi_{\Delta}=0,52\right)$. Os sítios de ligação entre os fotossensibilizadores e albumina bovina (BSA) são independentes e com células vermelhas de sangue humano (RBC) são cooperativos, com um e quatro sítios de ligação por molécula, respectivamente. As constantes de associação com BSA são $(1,15 \pm 0,07) \times 10^{5} \mathrm{e}(2,6 \pm 0,1) \times 10^{4} \mathrm{~L} \mathrm{~mol}^{-1} \mathrm{e}$ com RBC são $(2,40 \pm 0,05) \times 10^{7} \mathrm{~L} \mathrm{~mol}^{-1} \mathrm{e}$ $(7,2 \pm 0,2) \times 10^{4} \mathrm{~L} \mathrm{~mol}^{-1}$ para InTPP e Photofrin ${ }^{\circledR}$, respectivamente. O InTPP foi mais eficiente do que Photofrin ${ }^{\circledR}$ em fotooxidar L-triptofano (Trp) e BSA quando maiores concentrações dos fotossensibilizadores foram utilizadas (acima de $14 \mu \mathrm{mol} \mathrm{L}^{-1}$ ). O InTPP foi 1,37 a 1,5 vezes mais eficaz em fotooxidar as RBC do que Photofrin ${ }^{\circledR}$. Nossos resultados indicam que o InTPP pode ser usado para estudos futuros de PDT.
\end{abstract}

Photodynamic activity of chloro(5,10,15,20-tetraphenylporphyrinato)indium(III) (InTPP) in vitro was investigated for possible use in photodynamic therapy (PDT). The quantum yield of singlet oxygen generation in DMSO of $\operatorname{InTPP}\left(\Phi_{\Delta}=0.72\right)$ was higher than 5,10,15,20-tetraphenylporphyrin (TPP) $\left(\Phi_{\Delta}=0.52\right)$. Binding sites between photosensitizers and bovine serum albumin (BSA) are independent while binding sites with human red blood cells (RBC) are cooperatives, with one and four binding sites per molecule, respectively. Binding constants with BSA are $(1.15 \pm 0.07)$ $\times 10^{5}$ and $(2.6 \pm 0.1) \times 10^{4} \mathrm{~L} \mathrm{~mol}^{-1}$ and with $\mathrm{RBC}$ are $(2.40 \pm 0.05) \times 10^{7} \mathrm{~L} \mathrm{~mol}^{-1} \mathrm{e}(7.2 \pm 0.2) \times$ $10^{4} \mathrm{~L} \mathrm{~mol}^{-1}$ for InTPP and Photofrin ${ }^{\circledR}$, respectively. InTPP was more efficient than Photofrin ${ }^{\circledR}$ in the photooxidation of L-tryptophan(Trp) and BSA when higher concentrations $\left(14 \mu \mathrm{mol} \mathrm{L} \mathrm{L}^{-1}\right)$ of photosensitizers were used. InTPP was 1.37-1.5 times more effective in the photooxidation of RBC than Photofrin ${ }^{\circledR}$. Our results indicate that InTPP should be used in future studies of PDT.

Keywords: indium(III)-meso-tetraphenylporphyrin, PDT, quantum yield, hemolysis, singlet oxygen

\section{Introduction}

Photodynamic therapy (PDT) is a therapeutic modality used in the treating neoplastic diseases and in other applications, such as sterilizing freshly frozen plasma, treating actinic keratosis, choroidal neovascularization from macular degeneration and pathological myopia. ${ }^{1-7}$ Photodynamic activation has also found use for treatment of wastewater and sunlight-activated herbicides and insecticides. ${ }^{89}$ In the treatment of neoplastic diseases,

\footnotetext{
*e-mail: rjorge@iqm.unicamp.br
}

photosensitizers are normally used in special drug delivery systems, which preferentially accumulate in the target cells. Subsequent irradiation of the lesion with an adequate light source leads to the destruction of the target cell by the local generation of toxic radicals (type I mechanism) and/ or singlet oxygen (type II mechanism). ${ }^{1-3}$

Some photophysical properties have been identified as essential in an efficient sensitizer for PDT, such as a long lifetime of the excited triplet state, low fluorescence quantum yield $\left(\Phi_{\mathrm{f}}\right)$, deactivation directed by the singlet excited state, and a high quantum yield of singlet oxygen generation. ${ }^{1-3}$ The success of PDT requires an optimal correlation between the physical and chemical parameters of the photosensitizer, 
its pharmacological properties (pharmacokinetic and pharmacodynamic behaviors in biological tissue), and its phototherapeutic properties in vivo. ${ }^{10}$ In this context, new designs of photosensitizing agents have been studied, in which their chemical properties were modified, including the size of the macrocycle and the nature of the peripheral groups. ${ }^{11-15}$ The coordination of the central metal ion in phthalocyanines and porphyrinic structures influences the formation of reactive oxygen species and the mechanism of target cell destruction. ${ }^{16-17}$ Rosenfeld et al. ${ }^{18}$ and Chen et $a l .{ }^{19}$ showed that the presence of indium(III) in the core of a series of pyropheophorbide enhanced their photosensitizing efficiency in vitro and in vivo. The overall lipophilicity of the macrocycle plays a significant role in the photodynamic efficiency of sensitizers. ${ }^{18}$ Jezek et al. ${ }^{20}$ showed that lower doses of TPP-loaded liposome were more efficient in vivo than hydrophilic meso-tetra(4-sulfonatophenyl)porphine (TPPS4) or commercial Photosan-3®.

The general objective of the present study was to evaluate the photosensitizer activity of InTPP in vitro. The specific aims were: $(i)$ determination of $\Phi_{\Delta}, \Phi_{\mathrm{f}}$, and the triplet state lifetime $\left(\tau_{\mathrm{T}}\right)$ of InTPP and comparison of these photophysical properties with those of the free-base porphyrin (TPP), to obtain information about the effect produced by the formation of the metal complex with In(III); (ii) comparison of the efficiency of InTPP with that of Photofrin® in photooxidation of Trp, BSA, and RBC; and (iii) correlation of BSA and RBC affinities of InTPP and Photofrin $®$ with their photosensitizer activities.

\section{Experimental}

\section{Reagents}

InTPP and 5,10,15,20-tetrakis(4-N-methylpyridyl) porphyrin $\left(\mathrm{TMPyPH}_{2}\right.$; pharmaceutical grade, > $95 \%$ pure) were purchased from Frontier Scientific Inc (Logan, UT, USA). Photofrin ${ }^{\circledR}$ (haematoporphyrin derivative, pharmaceutical grade) was from Axcan Pharma Inc. (Mont-Saint-Hilaire, Quebec, Canada). BSA, Trp, polyoxyethylene sorbitan monolaurate (Tween $\left.{ }^{\circledR} 20\right), N, N$-dimethylformamide (DMF), and ethylenediaminetetraacetic acid (EDTA) were purchased from Sigma Chemical Company (St Louis, MO, USA) and $\mathrm{NaCl}, \mathrm{KCl}, \mathrm{Na}_{2} \mathrm{HPO}_{4} \bullet 7 \mathrm{H}_{2} \mathrm{O}$, and $\mathrm{NaH}_{2} \mathrm{PO}_{4} \bullet \mathrm{H}_{2} \mathrm{O}$ were purchased from Merck (Whitehouse Station, NJ, USA). The RBC used in the hemolysis assays were donated by the Hospital de Clínicas of the Universidade Estadual de Campinas, according to the Ethical Human Protocols of the Faculdade de Ciências Médicas of the Universidade Estadual de Campinas.

\section{Steady-state measurements}

Electronic absorption measurements of InTPP $\left(1.0 \mu \mathrm{mol} \mathrm{L}^{-1}\right)$ and TPP $\left(1.0 \mu \mathrm{mol} \mathrm{L}{ }^{-1}\right)$ were made using samples in DMSO, with a Hewlett Packard 8453A Diode Array Spectrophotometer. Fluorescence quantum yields were determined using an ISS $® P C 1^{\mathrm{TM}}$ photon counter with TPP in DMSO as the standard, with $\Phi_{\mathrm{f}}=0.13 .{ }^{21}$ Absorbances of the standard $\left(0.03 \mu \mathrm{mol} \mathrm{L}-1, \lambda_{\text {excitation }}=418 \mathrm{~nm}\right)$ and $\operatorname{InTPP}\left(0.03 \mu \mathrm{mol} \mathrm{L}{ }^{-1}, \lambda_{\text {excitation }}=426 \mathrm{~nm}\right)$ were lower than 0.05 to avoid internal filter effects. The fluorescence quantum yield for each sample was measured using the ratio method described by Eaton. ${ }^{22}$

\section{Triplet state lifetime measurements}

Triplet state lifetime measurements of InTPP in DMSO were made using a laser flash photolysis spectrometer, which allowed the simultaneous capture of the transient absorption spectrum $(\lambda=300-800 \mathrm{~nm})$ and the transient kinetics at a single wavelength. Solutions were deaerated by nitrogen bubbling. The InTPP concentrations $\left(27 \mu \mathrm{mol} \mathrm{L}^{-1}\right)$ at $355 \mathrm{~nm}$ were adjusted in order to obtain an absorbance on the order of 0.4 , what assure a good population of the excited state and all further process. The triplet state was studied by laser flash photolysis, as previously described, using a system reported in detail elsewhere. ${ }^{23,24}$ Briefly, the system uses the third harmonic $(355 \mathrm{~nm})$ of an Nd-YAG laser. The pulse length was $8 \mathrm{~ns}$, the beam diameter incident on the sample was $6 \mathrm{~mm}$, and the repetition rate was $10 \mathrm{~Hz}$. The pulse energy was typically $30 \mathrm{~mJ}$ per pulse as measured with a Field Master power meter with L-30V head. A $400 \mathrm{~W}$ tungsten-halogen lamp was used as the probe. The lamp beam is collimated ( $1 \mathrm{~mm}$ in diameter) through the sample in the cell holder, which is held in a cuvette $1 \mathrm{~cm}$ pathlenght. The growth-decay kinetics were measured at a single wavelength using a monochromator (M300 from Bentham), and a photomultiplier (Hamamatsu, model R928P). Transient decays were averaged using a Tetronix TDS 340A digital oscilloscope. The stored digitized kinetic decays were transferred to a personal computer (PC) for analysis with software supplied by Edinburgh Instruments (Livingston, UK). Pheophorbide-a $\left(10 \mu \mathrm{mol} \mathrm{L}^{-1}\right)$ in DMSO was used as the standard to evaluate the triplet lifetime $(100 \mu \mathrm{s}) .^{25}$

\section{Quantum yield of singlet oxygen generation}

Singlet oxygen measurements were based on direct determination by infrared luminescence measurements at $1270 \mathrm{~nm}$, using a system reported in detail elsewhere. ${ }^{24}$ The 
$\Phi_{\Delta}$ measurements for InTPP were carried out in DMSO, using pheophorbide-a in deuterated ethanol as the reference $\left(\Phi_{\Delta}=0.59\right)^{26}$. The absorbance of InTPP $\left(27 \mu \mathrm{mol} \mathrm{L}^{-1}\right)$ and pheophorbide-a $\left(10 \mu \mathrm{mol} \mathrm{L}{ }^{-1}\right)$ was 0.4 at $355 \mathrm{~nm}$. The solutions were saturated with high-purity $\mathrm{O}_{2}$ for $40 \mathrm{~min}$ before the measurements were made.

The apparatus used in this procedure is the same as that described for the triplet excited state, with small changes. The excitation laser and setup was the same. However, a Germanium Detector model 823A from North Coast Scientific Corporation (Worcestershire, UK-England), operating in a nitrogen-cooled system substituted the photomultiplier. The signal was transferred to the same digital oscilloscope and analysis was carried out with a software supplied by Edinburgh Instruments. A silicon filter was used to avoid any fluorescence signal interferred with the singlet oxygen luminescence. Measurements were conducted using different concentrations and different laser intensities and the observed linearity with zero intercept rules out unwanted phenomena such as ground-state depletion, excited-state self-annihilation or multiphotonic absorption.

\section{Dimerization constants of InTPP}

InTPP is a hydrophobic compound and the dimerization constant of InTPP $\left(\mathrm{K}_{\mathrm{D}}\right)$ was determined by the Margalit method. ${ }^{27}$ This method linearizes the data from measurements of fluorescence intensity $(F)$ and has two basic hypotheses: (a) dimers are the dominant aggregates at low concentrations; $(b)$ only the monomer fluoresces, since porphyrins are known to produce dimers and aggregates that are non-fluorescent. ${ }^{27} \mathrm{~K}_{\mathrm{D}}$ was calculated by equation 1 :

$\frac{[\operatorname{InTPP}]_{\text {total }}}{\mathrm{F}}=2 \frac{\mathrm{K}_{\mathrm{D}}}{\mathrm{k}^{2}} \mathrm{~F}+\frac{1}{\mathrm{k}}$

where $[\mathrm{InTPP}]_{\text {total }}=[\operatorname{InTPP}]_{\text {monomer }}+[\operatorname{InTPP}]_{\text {dimer }} \mathrm{k}$ is a proportionality constant, $\mathrm{F}=\mathrm{k}[\mathrm{InTPP}]_{\text {monomer }}$, and $\mathrm{K}_{\mathrm{D}}$ was determined by the slope of the straight line of equation 1. The absorbance of InTPP (0.01-0.04 $\left.\mu \mathrm{mol} \mathrm{L}^{-1}\right)$ at the excitation wavelength were lower than 0.05 to assure a direct proportionality between the emitted fluorescence intensity and the concentration of the monomer. InTPP was dissolved in DMF and them added to an aqueous solution containing phosphate-buffered saline (PBS; pH 7.4), and Tween ${ }^{\circledR} 20\left(0.45 \mathrm{mmol} \mathrm{L}^{-1}\right)$. The final concentration of DMF was $5 \% \mathrm{v}: \mathrm{v}$. The concentration of Tween ${ }^{\circledR} 20$ was kept above its critical micellar concentration (CMC; $\left.0.04 \mathrm{mmol} \mathrm{L}^{-1}\right) .{ }^{28}$ Samples contained in a $1 \mathrm{~cm}$ pathlength quartz cuvette were excited at $427 \mathrm{~nm}$ and the fluorescence emitted by InTPP was recorded between $580 \mathrm{~nm}$ and 700 $\mathrm{nm}$. The experiments were carried out in triplicate.

Irradiation system and light dose absorbed by photosensitizers

The irradiation system consisted of a mercury lamp (Phillips ${ }^{\circledR}$ HPLN 80W) cooled by a water jacket compartment, which absorbs the infrared radiation emitted by the lamp, and an Oriel BG 38 filter, which allows the passage of radiation between $400 \mathrm{~nm}$ and $600 \mathrm{~nm}$. The radiaton emitted $\left(\mathrm{I}_{\mathrm{o}}\right)$ was $6.27 \mathrm{~mW} \mathrm{~cm}^{-2}$ as measured with a spectroradiometer (LI-1800, LI-COR Instruments, Lincoln, NE, USA). The vials with solutions of Trp, BSA and RBC were placed $5 \mathrm{~cm}$ from the lamp and were then irradiated for the desired time. The solutions were bubbled with $\mathrm{O}_{2}$ to ensure saturation. The value of the irradiance absorbed by the photosensitizer solutions at each wavelength $\left(\mathrm{I}_{\text {photo }, \lambda}\right)$ was calculated from the intensity of the incident light $\left(\mathrm{I}_{0}\right)$ by Beer's law:

$$
\mathrm{I}_{\text {photo }, \lambda}=\mathrm{I}_{\mathrm{o}, \lambda}[1-\exp (-2.3 \mathrm{~A})]
$$

where $A$ is the absorbance of InTPP and Photofrin $\AA$ (0.3-42.0 $\left.\mu \mathrm{mol} \mathrm{L}^{-1}\right)$. A was measured at each wavelength before irradiation of the samples. The total irradiance absorbed by the photosensitizer $\left(\mathrm{I}_{\text {photo }}\right)$ was calculated as:

$\mathrm{I}_{\text {photo }}=\sum_{\lambda} \mathrm{I}_{\text {photo }, \lambda}$

The dose of light absorbed by the photosensitizer in order to oxidize the substrate (in $\mathrm{J} \mathrm{cm}^{-2}$ ) was calculated as $\mathrm{I}_{\text {photo }} \times \mathrm{t}$, where $\mathrm{t}$ is the irradiation time required for oxidation (in seconds).

\section{Trp and BSA photooxidations}

Solutions of $\operatorname{Trp}\left(150 \mu \mathrm{mol} \mathrm{L}{ }^{-1}\right)$ and BSA $\left(23.5 \mu \mathrm{mol} \mathrm{L}^{-1}\right)$ in phosphate-buffered saline (PBS, pH 7.4) DMF (5\% v:v), and Tween ${ }^{\circledR} 20\left(8.94 \mathrm{mmol} \mathrm{L}^{-1}\right)$, containing InTPP or Photofrin ${ }^{\circledR}\left(1.0-42.0 \mu \mathrm{mol} \mathrm{L}{ }^{-1}\right)$ were irradiated in a total volume of $3 \mathrm{~mL}$. The emission fluorescences $(\mathrm{F})$ of Trp and BSA were monitored using an ISS ${ }^{8} \mathrm{PC}^{\mathrm{TM}}$ photon counting spectrofluorimeter. Trp and BSA excitation was at $280 \mathrm{~nm}$ and $F$ was measured at $355 \mathrm{~nm}$ and $324 \mathrm{~nm}$, respectively. Plots of ln $\mathrm{F}$ against time for Trp and BSA gave a straight line from which the rate constant was calculated. The half-life $\left(\mathrm{t}_{50}\right)$ and dose of light absorbed to oxidize $50 \%$ of the substrate were calculated as described in the previous section. 


\section{Hemolysis of $R B C$}

Photohemolysis can be measured by two procedures: hemolysis during irradiation ("continuum" photohemolysis, $\mathrm{CPH}$ ) or postirradiation hemolysis ("delayed" photohemolysis, DPH). In this work, CPH was measured.

Human blood of single donator was collected $48 \mathrm{~h}$ before the hemolysis assays in a tube containing EDTA, which was used as an anticoagulant. The tube was kept in a freezer until the moment of use. The serum was separated from the erythrocytes by centrifugation at $780 \times \mathrm{g}$ for 10 min. The $\mathrm{RBC}$ were washed with $\mathrm{NaCl}$ solution (0.85\% m:v) using three times the blood volume and then the cells were centrifuged at $1760 \times \mathrm{g}$ for $10 \mathrm{~min}$ to reduce the anticoagulant and serum residues. This procedure was repeated three times. RBC solutions $(4 \mathrm{~mL}$ and $1.89 \times 10^{10}$ cells $\mathrm{L}^{-1}$ ) containing PBS ( $\left.\mathrm{pH} 7.4\right)$, Tween ${ }^{\circledR} 20$ $\left(0.45 \mathrm{mmol} \mathrm{L}^{-1}\right), \mathrm{DMF}(1.6 \% \mathrm{v}: \mathrm{v})$ and InTPP or Photofrin $\AA$ (0.3-23.8 $\left.\mu \mathrm{mol} \mathrm{L}{ }^{-1}\right)$ were irradiated for 60 min using the photooxidation system previously described. Photofrin $®$, which is a water-soluble drug, was directly solubilized in the solution containing PBS, Tween $20 \AA$ and DMF while InTPP was initially solubilized in DMF and later added to the solution containing PBS, Tween 20® and DMF. Samples of $550 \mu \mathrm{L}$ were collected at intervals of $10 \mathrm{~min}$ and centrifuged at $500 \times \mathrm{g}$ for $5 \mathrm{~min}$. The supernatant was analyzed using a Hewlett Packard 8453A Diode Array Spectrophotometer at a wavelength of $542 \mathrm{~nm}$ to measure the oxyhemoglobin chromophore released from the erythrocytes as a result of the destruction of the RBC by the photodynamic action of the photosensitizer. The percentage hemolysis achieved with the photodynamic action was calculated by equation 4 :

$\frac{100\left(\mathrm{~A}_{1}-\mathrm{A}_{2}\right)}{\mathrm{A}_{\mathrm{T}}} \%$

where $A_{1}$ is the absorbance of the supernatant from the solution that contains the photosensitizer, $A_{2}$ is the absorbance of the control (without photosensitizer), and $A_{T}$ is the absorbance of total hemolysis, which is calculated from the lysis of the erythrocytes with an ultrasound cell disrupter (Ney ULTRAsonik ${ }^{\mathrm{TM}}$ ultrasonic system).

\section{Binding of sensitizers to BSA and erythrocytes}

Suppose that a protein $\mathrm{P}$ with $n$ binding sites reacts with a low molar mass ligand L. The microscopic equilibriums may be defined as follows:

$$
\begin{aligned}
& \mathrm{P}+\mathrm{L}=\mathrm{PL}_{1}, \quad \mathrm{~K}_{1}=\frac{\left[\mathrm{PL}_{1}\right]}{[\mathrm{P}][\mathrm{L}]} \\
& \mathrm{PL}_{1}+\mathrm{L}=\mathrm{PL}_{2}, \mathrm{~K}_{2}=\frac{\left[\mathrm{PL}_{2}\right]}{\left[\mathrm{PL}_{1}\right][\mathrm{L}]} \\
& \mathrm{PL}_{\mathrm{n}-1}+\mathrm{L}=\mathrm{PL}_{\mathrm{n}}, \quad \mathrm{K}_{\mathrm{n}}=\frac{\left[\mathrm{PL}_{\mathrm{n}}\right]}{\left[\mathrm{PL}_{\mathrm{n}-1}\right][\mathrm{L}]} \\
& {[\mathrm{L}]_{\text {bound }}=\left[\mathrm{PL} \mathrm{L}_{1}\right]+2\left[\mathrm{PL}_{2}\right]+\ldots \ldots+\mathrm{n}[\mathrm{PL}]} \\
& {[\mathrm{P}]_{\text {total }}=[\mathrm{P}]+\left[\mathrm{PL} \mathrm{L}_{1}\right]+\ldots \ldots . .+\left[\mathrm{PL} \mathrm{n}_{\mathrm{n}}\right]} \\
& {\left[\mathrm{PL}{ }_{1}\right]=\mathrm{K}_{1}[\mathrm{P}][\mathrm{L}],\left[\mathrm{PL}_{2}\right]=\mathrm{K}_{1} \mathrm{~K}_{2}[\mathrm{P}][\mathrm{L}]^{2},\left[\mathrm{PL}_{\mathrm{n}}\right]=} \\
& \mathrm{K}_{1} \mathrm{~K}_{2} \ldots . . \mathrm{K}_{\mathrm{n}-1} \mathrm{~K}_{\mathrm{n}}[\mathrm{P}][\mathrm{L}]^{\mathrm{n}}
\end{aligned}
$$

The mean ratio of $[\mathrm{L}]_{\text {bound }}$ to the total concentration of the $\mathrm{P}$ cells (cell number $\mathrm{L}^{-1}$ ) is:

$$
v=\frac{[\mathrm{L}]_{\text {bound }}}{[\mathrm{P}]_{\text {total }}}=\frac{[\text { sites occupied }]}{[\text { sites total }]}
$$

Therefore, from the last equations (8), (9), (10) and (11) $v$ can be rewritten as:

$v=\frac{\mathrm{K}_{1}[\mathrm{~L}]+2 \mathrm{~K}_{1} \mathrm{~K}_{2}[\mathrm{~L}]^{2}+\ldots . .+\mathrm{n}\left(\mathrm{K}_{1} \mathrm{~K}_{2} \ldots . . \mathrm{K}_{\mathrm{n}}\right)[\mathrm{L}]^{\mathrm{n}}}{1+\mathrm{K}_{1}[\mathrm{~L}]+\mathrm{K}_{1} \mathrm{~K}_{2}[\mathrm{~L}]^{2}+\ldots . .+\left(\mathrm{K}_{1} \mathrm{~K}_{2} \ldots . . \mathrm{K}_{\mathrm{n}}\right)[\mathrm{L}]^{\mathrm{n}}}$

For highly cooperative binding, the association of a molecule $\mathrm{L}$ on one site of $\mathrm{P}$ may thermodynamically influence the binding with all the other sites. In these conditions, only the concentrations of $\mathrm{P}$ and $\mathrm{PL}_{\mathrm{n}}$ are not negligible and equation (12) can be simplified to: ${ }^{29}$

$$
v=\frac{n K[L]^{n}}{1+K[L]^{n}} \quad(13), \text { where } K=K_{1} K_{2} \ldots . K_{n}
$$

The apparent binding association constant $(\mathrm{K})$ between photosensitizer and erythrocytes was calculated by using equation 13 . One $\mathrm{mL}$ of $\mathrm{RBC}$ at a total concentration $\left(\left[\mathrm{P}_{\text {total }}\right]\right)$ of $1.1 \times 10^{11}$ cells $\mathrm{L}^{-1}$ in a solution containing PBS (pH 7.4), Tween® 20 (0.45 mmol L $\left.{ }^{-1}\right)$ and DMF $(1.6 \% \mathrm{v}: \mathrm{v})$, were incubated in the dark in the presence of photosensitizer concentrations ranging from 1.0 to $8.0 \mu \mathrm{mol} \mathrm{L}-1$ for $30 \mathrm{~min}$ and then centrifuged at $500 \times \mathrm{g}$ for $5 \mathrm{~min}$. The concentration of the free photosensitizer [L] was determined spectrofluorimetrically, based on a previously constructed calibration curve. $[\mathrm{L}]_{\text {bound }}$ in equation 11 was calculated by: $[\mathrm{L}]_{\text {bound }}=[\mathrm{L}]_{\text {total }}-[\mathrm{L}]$.

Equation 13 may be rearranged to: 


$$
\frac{v}{\mathrm{n}-\mathrm{v}}=\frac{[\text { sites occupied }]}{[\text { sites vacant }]}=\mathrm{K}[\mathrm{L}]^{\mathrm{n}}
$$

The left side of equation 14 can be evaluated from spectrofluorimetric data of proteins, because:

$$
\frac{[\text { sites occupied }]}{[\text { sites vacant }]}=\frac{F_{0}-F}{F}
$$

where $\mathrm{F}_{\mathrm{o}}$ and $\mathrm{F}$ are fluorescence emissions of protein in the absence and presence of photosensitizer:

$$
\frac{\mathrm{F}_{\mathrm{o}}-\mathrm{F}}{\mathrm{F}}=\mathrm{K}[\mathrm{L}]^{\mathrm{n}}
$$

Equation 16 may be rearranged to:

$$
\ln \left(\frac{\mathrm{F}_{\mathrm{O}}-\mathrm{F}}{\mathrm{F}}\right)=\ln \mathrm{K}+\mathrm{n} \ln [\mathrm{L}]
$$

The apparent binding association constant $(\mathrm{K})$ between photosensitizer and BSA was calculated by using the "double-logarithmic" plot of equation 17. Three $\mathrm{mL}$ of BSA $\left(20 \mu\right.$ moles $\left.\mathrm{L}^{-1}\right)$ in PBS (pH 7.4), Tween ${ }^{\circledR} 20\left(0.45 \mathrm{mmol} \mathrm{L}^{-1}\right)$ and DMF (1.6\% v:v) was titrated spectrofluorimetrically by adding InTPP or Photofrin ${ }^{\circledR}$ in PBS (pH 7.4), Tween ${ }^{\circledR} 20\left(0.45 \mathrm{mmol} \mathrm{L}^{-1}\right)$ and DMF (1.6\% v:v) from a concentrated stock. The photosensitizer concentrations in the cuvette ranged from 3.0 to $20.0 \mu \mathrm{mol} \mathrm{L}^{-1}$. BSA excitation was made at $280 \mathrm{~nm}$ and emission fluorescence was measured at $324 \mathrm{~nm}$. In equation $17,[\mathrm{~L}]$ should be the free concentration of the InTPP or Photofrin ${ }^{\circledR}$, which is unknown. So, the total concentration of photosensitizer added in each aliquot of titration was used as [L]. The parameters $\mathrm{n}$ and $\mathrm{K}$ of equations 13 and 17 were evaluated using the software Origin ${ }^{\circledR} 7.5$ (OriginLab Inc, Northampton, MA, USA).

\section{Results and Discussion}

\section{Photophysical results}

The structures of InTPP and TPP and the absorption spectra of the InTPP and TPP in DMSO are shown in Figures 1 and 2, respectively.

InTPP presents three characteristic absorption bands in the visible region. The most intense band at $427 \mathrm{~nm}$ (B-band) is related to the transition from orbital $\mathrm{a}_{1 \mathrm{u}}$ to a degenerated orbital $\mathrm{e}_{\mathrm{g}}$ (referring to a vibronic transition $v_{0} \rightarrow v_{0}$ ). The other two bands (560 and $600 \mathrm{~nm}, \mathrm{Q}$-bands) are due to the transition from orbital $\mathrm{a}_{2 \mathrm{u}}$ to orbital $\mathrm{e}_{\mathrm{g}}$ (referring to a vibronic process

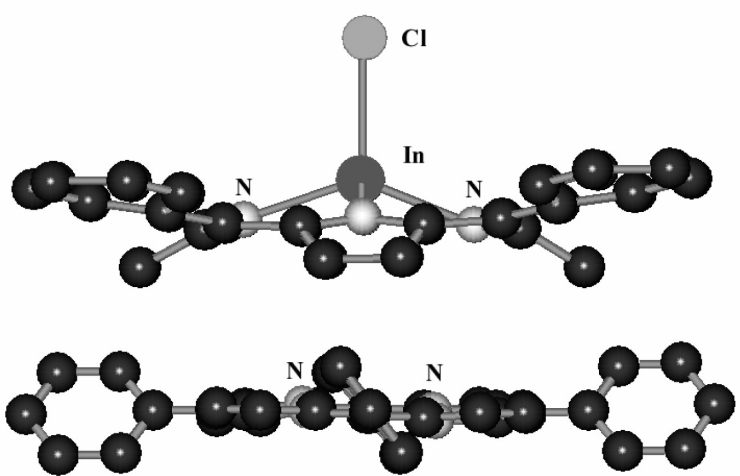

Figure 1. Computer-drawn structures of TPP and InTPP. These were generated with the molecular modeling program HyperChem 6.03 using the molecular mechanic method, and the model $\mathrm{MM}^{+}$to parameterize the force field that determine the potential energy as a function of the molecular configuration. The 18-membered porphine ring of TPP are in plane and the four phenyl groups are not. The presence of $\mathrm{In}-\mathrm{Cl}$ causes the 18-membered porphine ring of TPP to move out of the plane.

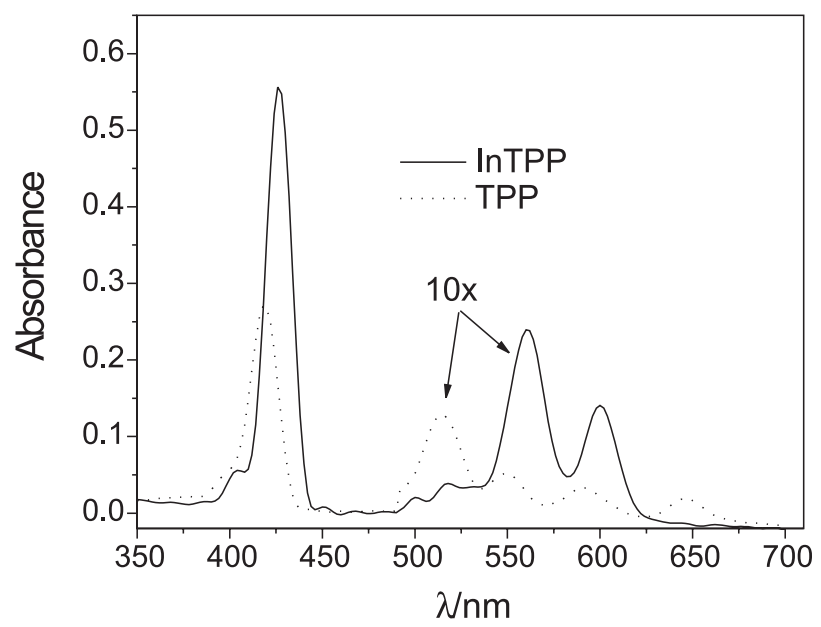

Figure 2. Electronic absorption spectra of InTPP $\left(1.0 \mu \mathrm{mol} \mathrm{L}^{-1}\right)$ and TPP $\left(1.0 \mu \mathrm{mol} \mathrm{L}^{-1}\right)$ in DMSO. Q bands were $10 \times$ enhancements in all peaks.

$v_{0} \rightarrow v_{0}$ and $v_{0} \rightarrow v_{1}$. The B-band for TPP is located at $418 \mathrm{~nm}$ while the Q-bands are located at $516 \mathrm{~nm}, 550 \mathrm{~nm}, 590$ and $646 \mathrm{~nm}$. The four bands for TPP are related to the presence of extra two hydrogens in the free base porphyrin that lead to a reduction of the overall porphyrin symmetry from the $D_{4} h$ type of metalloporphyrins to $\mathrm{D}_{2} \mathrm{~h} .{ }^{30}$ The structural changes in the basic structure of InTPP compared with those in TPP lead to a blue shift in the peak position of the long-wavelength $\mathrm{Q}$ band (646 nm for TPP versus $600 \mathrm{~nm}$ for InTPP). ${ }^{21}$ This blue shift is attributable to a distortion of the ligand plane caused by the central ion, ${ }^{31,32}$ and is also considered to be a measure of the degree of interaction between the central ion and the conjugated system..$^{29}$ The transient absorption spectrum obtained with laser flash photolysis of InTPP in DMSO is shown in Figure 3. The spectrum has a maximum transient absorption at $450 \mathrm{~nm}$ and is very similar to the 


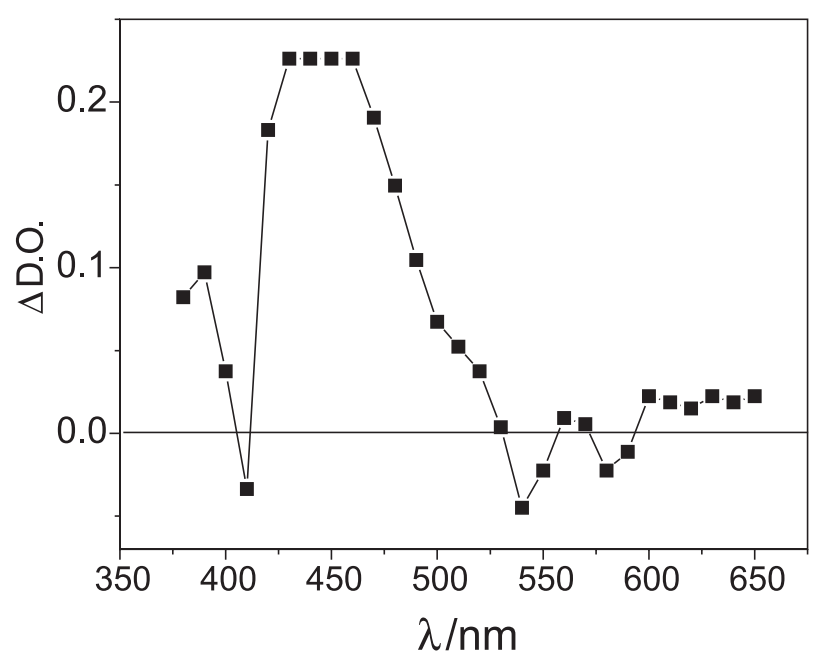

Figure 3. Transient absorbance spectrum of InTPP with excitation at a wavelength of $355 \mathrm{~nm}$ ( $30 \mathrm{~mJ}$ per pulse).

triplet-triplet absorption of metallotetraphenylporphyrins with diamagnetic central. ${ }^{33-35}$ The triplet lifetime of InTPP $(1.58 \pm 0.01 \mu \mathrm{s})$ is of the same order of magnitude as those usually found for porphyrins $(2.27 \mu \mathrm{s})$ in nitrogen bubbling methanol solutions. A similar result was obtained by Hoshino et al. ${ }^{34}$ with a value of $1.90 \mu \mathrm{s}$ for the triplet lifetime of InTPP in an aerated methanol solution and a transient peak maximum at $460 \mathrm{~nm}$. These values are sufficient to allow an efficient energy transfer process to molecular oxygen, leading to the production of singlet oxygen.

Table 1 presents the photophysical properties of InTPP and TPP. The extinction coefficient $(\varepsilon)$ values showed that InTPP absorbs more photons than TPP in the Q bands. The $\Phi_{\mathrm{f}}$ obtained for InTPP in DMSO (0.05) is in agreement with results reported in the literature for ethanol and benzene solutions. ${ }^{36}$ The $\Phi_{\mathrm{f}}$ of TPP in DMSO (0.13) was greater than that of InTPP (0.05). This was also observed for the fluorescence lifetime of InTPP $(0.8 \mathrm{~ns}$ in ethanol and $0.5 \mathrm{~ns}$ in benzene) compared with that of TPP (10.1 ns in ethanol and $12.4 \mathrm{~ns}$ in benzene). ${ }^{36,37}$ This behavior can be explained by the spin-orbit coupling induced by In(III), favoring the population of the triplet state. The results for $\Phi_{\Delta}$ show that InTPP in DMSO is a good generator of singlet oxygen compared with other derivatives of meso-tetraphenylporphyrin. ${ }^{38,39}$ Chloro(5,10,15,20-tetraphenylporphyrinato)gallium(III) (GaTPP), for example, has a $\Phi_{\Delta}$ value of 0.85 in toluene. ${ }^{40}$ For InTPP, the $\Phi_{\Delta}$ value measured in DMSO (0.72) is higher than the $\Phi_{\Delta}$ value of TPP (0.52) in the same solvent. ${ }^{21}$ The $\Phi_{\mathrm{f}}$ of TPP in DMSO is 2.6 times greater than that of InTPP, which leads to a higher deactivation of the singlet excited state and a slower intersystem crossing to the triplet state. The $\Phi_{\Delta}$ of InTPP in DMSO is 1.38 times greater than that of TPP. It is known that the quantum yield and lifetime of $S_{1}$ emissions are reduced with increases in the atomic number of the central metal ion. ${ }^{20}$ The enhancement of spin-orbit coupling in the atoms of higher atomic number results in the acceleration of the intersystem crossing $\mathrm{S}_{1} \rightarrow \mathrm{T}_{1}$ (heavyatom effect), increasing the triplet quantum yield $\left(\Phi_{\mathrm{T}}\right)$. The $\tau_{\mathrm{T}}$ value of TPP in DMSO was obtained from equation (3) of Korinek et al. ${ }^{21}$ at same concentration of InTPP (27 $\mu \mathrm{mol} \mathrm{L} \mathrm{L}^{-1}$ ) used for measuring $\tau_{\mathrm{T}}$ of InTPP. The $\tau_{\mathrm{T}}$ of TPP is 50 times greater than InTPP. $\Phi_{\Delta}$ depends of the absorption of light, the $\Phi_{\mathrm{T}}$, on the trapping efficiency of the triplet state by molecular oxygen within its lifetime and energy transfer from the triplet state to molecular oxygen. ${ }^{41}$ We observed that although the lifetime of the triplet state of InTPP is lower than for TPP the quantum yield of the singlet oxygen of InTPP is larger than for TPP, suggesting from this data that the triplet state lifetime of $1.58 \mu$ s of InTPP is larger than that for the trapping process.

Table 1. Photophysical properties of InTPP and TPP

\begin{tabular}{lcccccc}
\hline Sensitizer & Solvent & $\lambda_{\max } / \mathrm{nm}$ & $\begin{array}{c}\varepsilon_{\max }{ }^{\prime} \\
\left(\mathrm{L} \mathrm{mol}^{-1} \mathrm{~cm}^{-1}\right)\end{array}$ & $\tau / \mu \mathrm{s}^{\mathrm{a}}$ & $\phi_{\mathrm{f}}^{\mathrm{a}}$ & $\Phi_{\Delta}{ }^{\mathrm{b}}$ \\
\hline InTPP & DMSO & $427, \mathrm{~B}$ & $799,973^{\mathrm{d}}$ & $1.58^{\mathrm{d}}$ & $0.05^{\mathrm{d}}$ & $0.72^{\mathrm{d}}$ \\
& & $560, \mathrm{Q}$ & 26,779 & & & \\
& & $600, \mathrm{Q}$ & 16,189 & & & \\
\hline TPP & DMSO & $418, \mathrm{~B}$ & $354,480^{\mathrm{d}}$ & $79.1^{\mathrm{e}}$ & $0.13^{\mathrm{f}}$ & $0.52^{\mathrm{e}}$ \\
& & $516, \mathrm{Q}$ & 14,084 & & & \\
& & $550, \mathrm{Q}$ & 5,814 & & & \\
& & $590, \mathrm{Q}$ & 3,650 & & & \\
& & $646, \mathrm{Q}$ & 2,442 & & & \\
\hline
\end{tabular}

${ }^{a}$ nitrogen bubbling solutions; ${ }^{b}$ oxygen-saturated solutions; B, B-band; Q, Q-band; ${ }^{\mathrm{d}}$ this work; ${ }^{\mathrm{e}}$ ref 21; ${ }^{\mathrm{f}}$ ref 61.

\section{Dimerization of InTPP}

Margalit's plot (equation 1) was linear in the interval from 0.005 to $0.04 \mu \mathrm{mol} \mathrm{L}^{-1}$ InTPP (results not shown) indicating that for concentrations above of $0.04 \mu \mathrm{mol} \mathrm{L}^{-1}$ the formation of dimers and other aggregates occurs. The dimerization constant of InTPP was $(4.7 \pm 0.2) \times$ $10^{7}$. The $\mathrm{K}_{\mathrm{D}}$ of InTPP was 110 times greater than the $\mathrm{K}_{\mathrm{D}}$ of deuteroporphyrin IX and mesoporphyrin IX. ${ }^{27}$ Deuteroporphyrin IX and mesoporphyrin IX contain two carboxyls in their structures and the polarity of these molecules diminishes the dimerization constant. Because InTPP does not possess polar groups, its dimerization constant is higher than those of these two porphyrins.

Trp and BSA photooxidations and binding of sensitizers to $B S A$

There are many papers in the literature that show the efficacy of TPP in photooxidizing biomolecules. ${ }^{42,43}$ Faustino 
et al..$^{44,45}$ evaluated the meso-tetraphenylporphyrin dimer derivative as a potential photosensitizer in PDT. Recently, Pegaz et al. ${ }^{46}$ showed that TPP-loaded nanoparticles exhibited more photothrombic efficiency than free TPP. The presence of the gallium atom in the core of TPP increased the quantum yield of singlet oxygen generation by $31 \% .^{40,47}$ This effect could cause a higher photooxidation efficiency. In the same way, it is expected that InTPP is more efficient than TPP due to the heavy atom effect that is present in both InTPP (as shown in the previous section) and GaTPP. Thus, we decided that it is more significant to compare the photooxidation induced by InTPP with that of the drug approved by FDA and already being used the clinical treatments.

The photooxidation of tryptophan was used to compare the photodynamic efficiencies of InTPP and Photofrin ${ }^{\circledR}$ in the oxidation of a simple biomolecule. The light dose required to photooxidize $50 \%$ of the biomolecule shows that InTPP and Photofrin ${ }^{\circledR}$ present approximately the same effectiveness in photooxidizing the amino acid at photosensitizer concentrations in the range of 5.9-14.0 $\mu \mathrm{mol} \mathrm{L}^{-1}$ (Figure 4). However, InTPP is more efficient than Photofrin ${ }^{\circledR}$ when higher concentrations (14.0-41.4 $\left.\mu \mathrm{mol} \mathrm{L} \mathrm{L}^{-1}\right)$ of photosensitizer were used in the experiment.

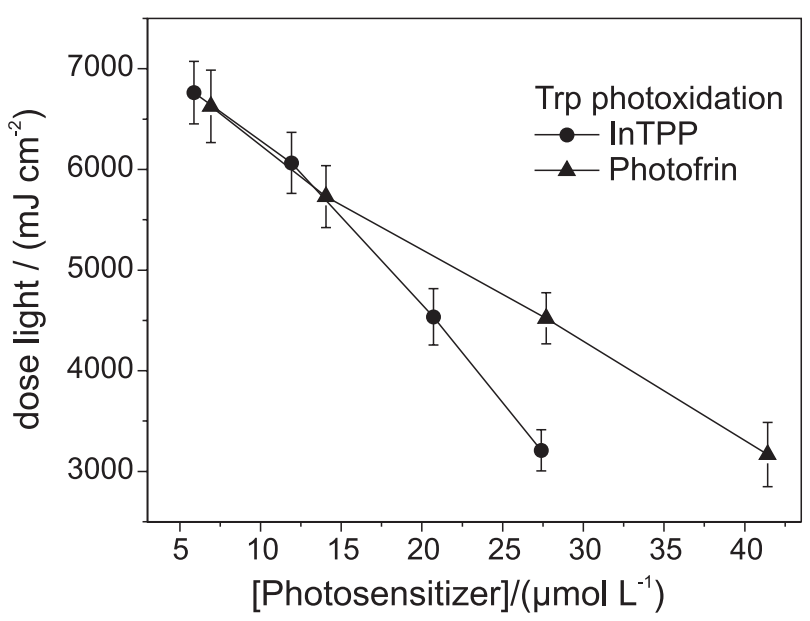

Figure 4. Photosensitizing activity of InTPP or Photofrin ${ }^{\circledR}$ with tryptophan $\left(175 \mu \mathrm{mol} \mathrm{L}^{-1}\right)$. Data represents mean $\pm \mathrm{SD}$ of three independent experiments.

In the oxidation of proteins by the photosensitizers the chains are degraded because of the presence of amino acids, such as cysteine, histidine, methionine, tryptophan, and tyrosine. The work of Silvester et al. ${ }^{48}$ determined that BSA photooxidation using hematoporphyrin or tetramethylpyridiniumporphyrin occurs at two different specific sites of the protein: at Trp-134 and/or Trp-214 residues and at the Cys-34 residue, respectively. Radicals were generated at tertiary carbons in tryptophan photooxidation and RS radicals were formed in cysteine photooxidation. In the case of tryptophan, the radical formation coincided with a fluorescence decrease in BSA ${ }^{48}$ The photodynamic efficiency of InTPP to oxidize proteins was investigated using BSA solutions, which were irradiated in the presence of different concentrations of the indium porphyrin. The results were compared with those for Photofrin ${ }^{\circledR}$. Figure 5 shows the dose of light absorbed to photooxidize $50 \%$ of BSA. The data show that Photofrin $\AA$ is more efficient than InTPP at photosensitizer concentrations in the range of 1.6-14.0 $\mu \mathrm{mol} \mathrm{L}^{-1}$. Nevertheless, InTPP is more efficient than Photofrin ${ }^{\circledR}$ at concentrations in the range $14.0-27.0 \mu \mathrm{mol} \mathrm{L}^{-1}$.

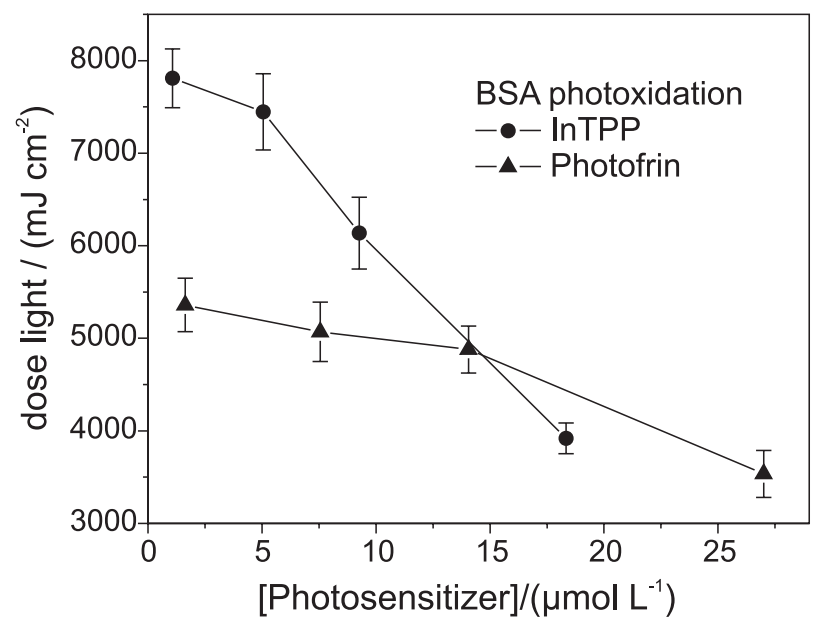

Figure 5. Photosensitizing activity of InTPP or Photofrin ${ }^{\circledR}$ with BSA $\left(23.5 \mu \mathrm{mol} \mathrm{L} \mathrm{L}^{-1}\right)$. Data represents mean $\pm \mathrm{SD}$ of three independent experiments.

The differences in the observed photooxidation efficiencies of InTPP and Photofrin ${ }^{\circledR}$ may be related to the aggregation of these compounds and to differences in the structures of BSA and Trp. Photofrin ${ }^{\circledR}$ is present in aqueous solution as monomers, dimers, trimers and other oligomeric species. A ratio of 14:19:67 for monomers, dimers and oligomers has been estimated for Photofrin $\circledR^{8}{ }^{49}$ The largest oligomer of Photofrin $₫$ contains nine monomeric units. ${ }^{50}$ As shown previously, InTPP dimerizes under the conditions of our experiments (above $0.04 \mu \mathrm{mol} \mathrm{L}^{-1}$ ). Even if trimers and other oligomers of InTPP occur, the fraction of large oligomers in Photofrin ${ }^{\circledR}$ at the higher concentrations is probably greater than that for InTPP, which would diminish the formation of singlet oxygen in the Photofrin ${ }^{\circledR}$ relative to InTPP, thus causing a reduction in the photodynamic efficiency of Photofrin ${ }^{\circledR}$ relative to that of InTPP in the photooxidation of Trp and BSA at these higher concentrations.

Serum albumin is a carrier for photosensitizers. ${ }^{51}$ Its binding affinity for drugs can play an important role in 
photodynamic efficiency. The photosensitizers can be bound with amino acids of serum albumin. However, only tryptophan presents a strong emission of fluorescence when part of a protein chains. ${ }^{52}$ Thus, the interactions between InTPP or Photofrin $®$ and BSA was studied by the fluorescence of tryptophan. The number of sites on the BSA capable of binding photosensitizers, derived from the slope of the linear plot of equation 17 (figure not shown) were $(1.06 \pm 0.06)$ and $(0.97 \pm 0.05)$ for InTPP and Photofrin $\AA$, respectively. The binding constants for BSA using intercepts of the linear plot of equation 15 were $(1.15 \pm 0.07) \times 10^{5}$ and $(2.6 \pm 0.1) \times 10^{4} \mathrm{~L} \mathrm{~mol}^{-1}$ for InTPP and Photofrin $\AA$, respectively. The binding sites are independent and identical and in InTPP are stronger than Photofrin ${ }^{\circledR}$. These results support the photodynamic efficiency observed with Photofrin $®$, as expected for its known photosensitizer properties, and for InTPP as shown in Figure 5. However, the correlation between photodynamic activity and affinity with BSA occurs when higher concentrations $\left(14.0 \mu \mathrm{mol} \mathrm{L}{ }^{-1}\right)$ of photosensitizers were used. This behavior could be explained as $\mathrm{K}$ is a practical constant and not a thermodynamic equilibrium constant. The value of $\mathrm{K}$ measures the interaction of photosensitizer monomer-BSA and all the other interactions such as photosensitizer dimer-BSA, photosensitizer trimerBSA, and photosensitizer oligomer-BSA. Therefore $\mathrm{K}$ is an average value of all these interactions, while the photodynamic efficiency is directly related with the quantum yield of singlet oxygen generation that can be diminished by the association of sensitizer molecules with oligomers, whose concentrations vary with the state of aggregation of the sensitizer. Our results are concordant with others reported in the literature. $\mathrm{K}$ and $\mathrm{n}$ values for chlorine e6-BSA are $1.62 \times 10^{5} \mathrm{~L} \mathrm{~mol}^{-1}$ and 1.086, and between riboflavin-BSA are $8.5 \times 10^{4} \mathrm{~L} \mathrm{~mol}^{-1}$ and $1.10 .^{53,54} \mathrm{~K}$ for norharmane (NHM), an efficient cancer cell photosensitizer, and BSA is $1.33 \times 10^{4} \mathrm{~L} \mathrm{~mol}^{-1} .^{55}$

\section{Erythrocyte hemolysis and binding of sensitizers to eryth- rocytes}

RBC have been used as a model to study the ability of compounds to induce a photooxidation process in cells in vitro, because of the ease and inexpensiveness of the assays. RBC hemolysis can occur from an osmotic-colloidal process, which results in salt and water retention by the cells. ${ }^{33,56}$ This causes the loss of membrane-selective permeability, resulting in cell swelling and the eventual rupture of the membrane. Hemolysis can also occur from the photooxidation of intrinsic proteins located in the membrane, which are bound to phospholipids, and/or by the photooxidation of the unsaturated phospholipids that constitute the erythrocyte membrane, causing the formation of pores and an increase in phospholipid mobility. This causes membranes to rupture, with the consequent release of oxyhemoglobin from the erythrocytes.

Surfactants also cause erythrocyte hemolysis through lipid and protein solubilization when the surfactant concentration is near or above the CMC. At lower concentrations, monomeric species of the surfactant interact with the hydrophobic region of the lipid bilayer. The nonpolar region of the surfactant is located within the lipid bilayer and the polar head group is located at the surface of the membrane. This causes an increase in membrane permeability, but without rupture. Therefore, care was taken to establish the percentages of Tween ${ }^{\circledR} 20\left(0.45 \mathrm{mmol} \mathrm{L}^{-1}\right)$ and DMF (1.6\% v:v) in the erythrocyte solutions, to minimize the hemolysis caused by the surfactant and the organic solvent itself.

Using the preestablished conditions described above, RBC solutions with different concentrations of InTPP and Photofrin ${ }^{\circ}\left(0.3-23.8 \mu \mathrm{mol} \mathrm{L} \mathrm{L}^{-1}\right)$ were irradiated with a mercury lamp. Figure 6 shows a typical photohemolysis curve with a sigmoidal shape, as reported by other researchers. ${ }^{57,58}$ It can be seen in Figure 6 that Photofrin $®$ required a longer times than InTPP to photooxidize RBC at all concentrations.

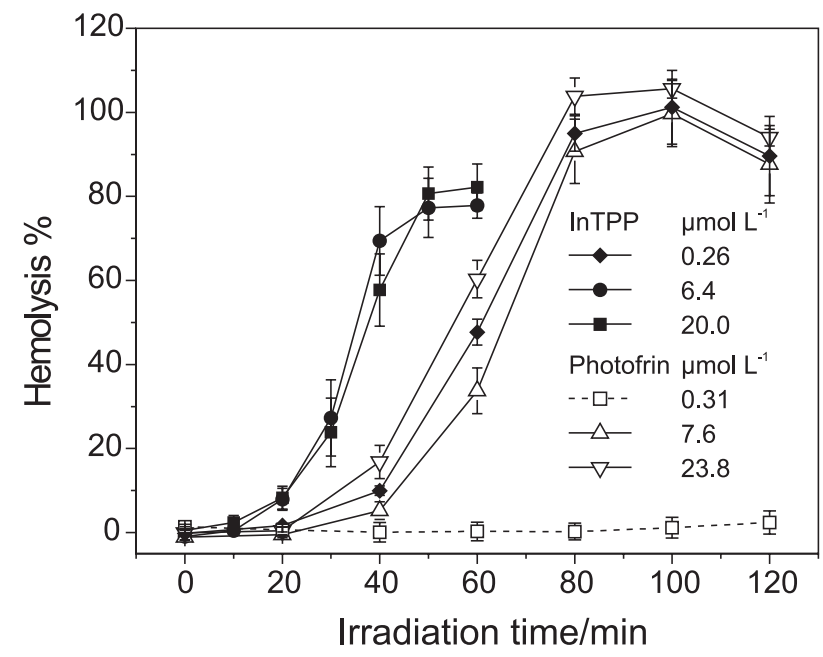

Figure 6. Delayed photohemolysis curves for human red blood cells $\left(1.89 \times 10^{10}\right.$ cells L $\left.{ }^{-1}\right)$ photosensitized by InTPP or Photofrin $®$. Data represents mean $\pm \mathrm{SD}$ of three independent experiments.

Table 2 presents irradiation times and light doses absorbed by the photosensitizers to inactivate $50 \%$ of the cell population. The light doses values indicate that InTPP was 1.5-1.37 times more effective in the photooxidation of RBC than Photofrin $®$, as the concentration of the photosensitizer was increased from 3.14 to $20.0 \mu \mathrm{mol} \mathrm{L}^{-1}$ 
Table 2. Irradiation times $\left(\mathrm{t}_{50}\right)$ and light doses absorbed by the photosensitizers to inactivate $50 \%$ of the cell population

\begin{tabular}{|c|c|c|c|c|c|}
\hline $\begin{array}{l}{[\text { InTPP }] /} \\
\left(\mu \text { moles } L^{-1}\right)\end{array}$ & $\mathrm{t}_{50} / \mathrm{min}$ & $\begin{array}{l}\text { Light doses/ } \\
\qquad\left(\mathrm{J} \mathrm{cm}^{-2}\right)\end{array}$ & $\begin{array}{c}{\left[\text { Photofrin }{ }^{\circledR}\right] /} \\
\left(\mu \text { moles L }{ }^{-1}\right)\end{array}$ & $\mathrm{t}_{50} / \mathrm{min}$ & $\begin{array}{l}\text { Light doses/ } \\
\left(\mathrm{J} \mathrm{cm}^{-2}\right)\end{array}$ \\
\hline 0.26 & $61.0 \pm 1.4$ & $660 \pm 50$ & 0.31 & $*$ & $*$ \\
\hline 3.14 & $45.1 \pm 1.6$ & $3600 \pm 200$ & 3.73 & $88.5 \pm 2.2$ & $5400 \pm 30$ \\
\hline 6.4 & $35.0 \pm 1.2$ & $4100 \pm 200$ & 7.6 & $65.8 \pm 1.9$ & $5900 \pm 300$ \\
\hline 20.0 & $37.8 \pm 2.1$ & $6700 \pm 400$ & 23.8 & $55.5 \pm 2.0$ & $9200 \pm 500$ \\
\hline
\end{tabular}

* Hemolysis was not observed.

of InTPP. Photoxidation did not occur when a lower concentration of Photofrin ${ }^{\circledR}$ was used $\left(0.35 \mu \mathrm{mol} \mathrm{L}^{-1}\right)$. Table 2 shows that there was a reduction in $\mathrm{t}_{50}$ when the concentration of InTPP was increased from 0.26 to $6.4 \mu \mathrm{mol} \mathrm{L}^{-1}$. However, there was almost no change in $\mathrm{t}_{50}$ when the concentration of InTPP was increased from 6.4 to $20.0 \mu \mathrm{mol} \mathrm{L}^{-1}$, possibly due to the formation of larger oligomers at higher InTPP concentrations in the presence of RBC. There was also a decrease in the maximum percentage hemolysis from $100 \%$ to around $82 \%$ when higher concentrations of InTPP $\left(6.4\right.$ and $\left.20 \mu \mathrm{mol} \mathrm{L}^{-1}\right)$ were used in the experiment. No changes were observed in the maximum percentage hemolysis when higher Photofrin ${ }^{\circledR}$ concentrations were used. Grossweiner et $a l .{ }^{57}$ reported that, in porphyrin-binding experiments with RBC, the bound sensitizer fraction decreased as the total sensitizer concentration increased. This suggests that increases in the porphyrin concentration favor the aggregation of its molecules. Therefore, it is possible that the microenvironment of erythrocytes does not change the aggregation state of Photofrin $®$, but favors the formation of InTPP aggregates, which decreases the percentage hemolysis to around $82 \%$.

Determination of the parameters $n$ and $K$ of equation 13 and using the data shown in Figure 7 showed that there are four cooperative binding sites per cell, with association constants of $(2.40 \pm 0.05) \times 10^{7} \mathrm{~L} \mathrm{~mol}^{-1}$ and $(7.2 \pm 0.2) \times 10^{4} \mathrm{~L} \mathrm{~mol}^{-1}$ for InTPP and Photofrin ${ }^{\circledR}$, respectively. These results show that InTPP has a higher affinity for erythrocytes than Photofrin $®$. The differences in the observed efficiencies could be associated with the affinity of the sensitizers for the erythrocyte membrane. Photodynamic activity of phthalocyanines was also observed to correlate with the affinity of the dye for the cell. ${ }^{59}$ The Davson-Danielli principle states that the ease with which a compound passes through the cellular membrane is proportional to its lipophilic character. ${ }^{60}$ Therefore, the higher polarity of Photofrin ${ }^{\circledR}$ molecules weakens their interaction with the membrane. Our results indicate that, because of the higher affinity of InTPP for RBC compared with that of Photofrin ${ }^{\circledR}$, a lower light

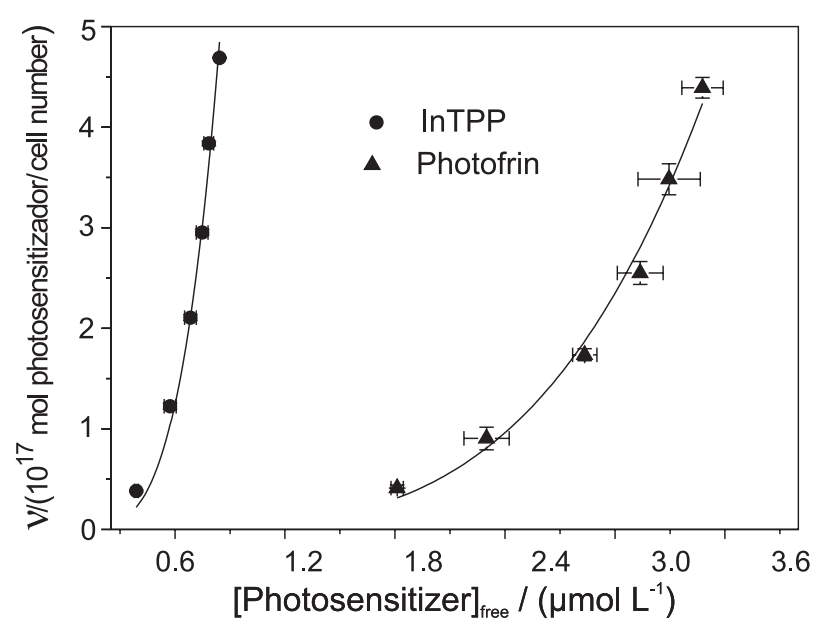

Figure 7. Binding of the photosensitizers to the erythrocytes. Sensitizers $\left(1.0-8.0 \mu \mathrm{mol} \mathrm{L}^{-1}\right)$ were incubated in the dark for $30 \mathrm{~min}$ in solutions containing erythrocytes $\left(1.1 \times 10^{11}\right.$ cells $\left.\mathrm{L}^{-1}\right)$, PBS $(\mathrm{pH} 7.4)$, Tween ${ }^{\circledR} 20$ $\left(0.45 \mathrm{mmol} \mathrm{L}^{-1}\right)$, and DMF (1.6\% v:v). Data represents mean \pm SD of three independent experiments.

dose is required for the indium porphyrin to inactivate $50 \%$ of the cell population, which demonstrates the higher efficiency of InTPP.

\section{Conclusions}

The presence of the indium atom in the structure of meso-tetraphenylporphyrin causes a decrease in the fluorescence quantum yield because of the enhancement of spin-orbit coupling. This results in an acceleration of the intersystem crossing and a consequent reduction in the yield and lifetime decay of the $S_{1}$ emission, which increases the quantum yield of singlet oxygen generation. InTPP was more efficient than Photofrin ${ }^{\circledR}$ in the photooxidation of Trp and BSA when higher concentrations of photosensitizer were used. The affinity of BSA for InTPP is high and plays an important role in photodynamic efficiency of InTPP. Erythrocyte photooxidation showed that InTPP is more efficient than Photofrin $®$ in causing the hemolysis of RBC, probably because InTPP has a greater affinity for sites on the RBC than does Photofrin ${ }^{\circledR}$, which results in shorter photohemolysis times for the indium porphyrin. 
This is an interesting property of PDT, because with faster photooxidation rates, shorter irradiation times are required to destroy diseased tissues. The photophysical properties and photodynamic activity of InTPP in vitro suggest that InTPP should be explored in further studies of PDT. Studies to encapsulate InTPP for this purpose are in progress in our laboratory.

\section{Acknowledgments}

The authors are grateful to the Hemocentro and to Cepagri of the Universidade Estadual de Campinas for supplying the blood for the experimental assays and for the irradiance measurements of the mercury lamp, respectively. We thank the Fundação de Amparo à Pesquisa do Estado de São Paulo (FAPESP) for financial support.

\section{References}

1. Bonnett, R.; Chem. Soc. Rev. 1995, 24, 19.

2. Via, L. D.; Magno, S. M.; Curr. Med. Chem. 2001, 8, 1405.

3. DeRosa, M. C.; Crutchley, R. J.; Coord. Chem. Rev. 2002, 233, 351.

4. Sharman, W. M.; Allen, G. M.; VanLier, J. E.; Drug Discov. Today 1999, 4, 507.

5. Kim, H. S.; Yoo, J. Y.; Cho, K. H.; Kwon, O. S.; Moon, S. E.; Dermatol. Surg. 2005, 31, 33.

6. Parodi, M. B.; Iacono, P.; Spasse, S.; Ravalico, G.; Am. J. Ophthalmol. 2006, 141, 123.

7. Varano, M.; Parisi, V.; Tedeschi, M.; Sciamanna, M.; Gallinaro, G.; Capaldo, N.; Catalano, S.; Pascarella, A.; Invest. Ophth. Vis. Sci. 2005, 46, 1453.

8. Esser, P.; Pohlmann, B.; Scharfet, H. D.; Angew. Chem. 1994, 106, 2093.

9. Amor, T. B.; Jori, G.; Insect Biochem. Mol. Biol. 2000, 30, 915.

10. Dickson, E. F. G.; Goyan, R. L.; Pottier, R. H.; Cell. Mol. Biol. 2003, 48, 939.

11. Ben-Dror, S.; Bronshtein, I.; Whiele, A.; Röder, B.; Senge, M. O.; Ehrenberg, B.; Photochem. Photobiol. 2006, 82, 695.

12. Kramer-Marek, G.; Serpa, C.; Szurko, A.; Widel, M.; Sochanik, A.; Snietura, M.; Kus, P.; Nunes, R. M. D.; Arnaut, L. G.; Ratuszna, A.; J. Photochem. Photobiol. B 2006, 84, 1.

13. Banfi, S.; Caruso, E.; Buccafurni, L.; Murano, R.; Monti. E.; Gariboldi, M.; Papa, E.; Gramatica, P.; J. Med. Chem. 2006, 49, 3293.

14. Whiele, A.; Shaker, Y. A.; Brandt, J. C.; Mebs, S.; Senge, M. O.; Tetrahedron 2005, 61, 5535.

15. Rancan, F.; Whiele, A.; Nobel, M.; Senge, M. O.; Omari, S. A.; Böhm, F.; John, M.; Röder, B.; J. Photochem. Photobiol. B 2005, 78, 17.
16. Vakrat-Hogalili, Y.; Weiner, L.; Brumfield, V.; Brandis, A.; Saloman, Y.; Mcllroy, B.; Wilson, B. C.; Pawlak, A.; Rozanowska, M.; Sarna, T.; Scherz, A.; J. Am. Chem. Soc. 2005, $127,6489$.

17. Finley, J. C.; Mitra, S.; Foster, T. H.; Photochem. Photobiol. 2002, 75, 282.

18. Rosenfeld, A.; Morgan, J.; Goswami, L. N.; Ohulchankyy, T.; Zheng, X.; Prasad, P. N.; Oseroff, A.; Pandey, R. K.; Photochem. Photobiol. 2006, 82, 626.

19. Chen, Y.; Zheng, X.; Dobhal, M. P.; Gryshuk, A.; Morgan, J.; Dougherty, T. J.; Oseroff. A.; Pandey, R. K.; J. Med. Chem. 2005, 48, 3692.

20. Jezek, P.; Nekvasil, M.; Skobisova, E.; Urbankova, E.; Jirsa, M.; Zadinova, M.; Pouckova, P.; Klepacek, N.; Int. J. Cancer 2003, 103, 693.

21. Korinek, M.; Dedic R.; Molnar, A.; Svoboda, A.; Hála, J.; J. Mol. Struct. 2005, 744, 727.

22. Eaton, F. D.; Pure Appl. Chem. 1988, 60, 1107.

23. Ermolenko, L. P.; Delaire, J. A.; Giannotti, C.; J. Chem. Soc., Perkin Trans. 1997, 2, 25.

24. Bautista-Sanchez, A.; Kasselouri, A.; Desroches, M.-C.; Blais, J.; Maillard, P.; Oliveira, M. D.; Tedesco, A. C.; Prognon P.; Delaire, J.; J. Photochem. Photobiol. B 2005, 81, 154.

25. Roder, B.; Hanke, T.; Oelckers, S.; Hackbarth, S.; Symietz, C.; J. Porphyr. Phthal., 2000, 4, 37.

26. Spiller, W.; Kliesch, H.; Wöhrle, D.; Hackbarth, S.; Röder B.; Schnurpfeil, G.; J. Porphyr. Phthal. 1998, 2, 145

27. Margalit, R.; Shaklai, N. Choen, S.; Biochemical J. 1983, 209, 547.

28. Hinze, W. L.; Pramauro, E.; Crit. Rev. Anal. Chem. 1993, 24, 133.

29. Holde, V.; Kensal, D.; Physical Biochemistry; Prentice-Hall, Inc, Englewood Cliffs: New Jersey, 1971, ch. 3.

30. Kalyanasundaram, K.; Photochemistry of Polypyridine and Porphyrin Complexes; $1^{\text {th }}$ ed., Academic Press: San Diego, 1992.

31. Rubio, N.; Prat, P.; Bou, N.; Borrell, J. I.; Teixidó, J.; Villanueva, Á.; Juarranz, Á.; Cañete, M.; Stockert, J. C.; Nonell, S.; New J. Chem. 2005, 29, 378.

32. Valicsek, Z.; Horvath, O.; Stevenson, K. L.; Photochem. Photobiol. Sci. 2004, 3, 669.

33. Foley, M. S. C.; Beeby, A.; Parker, A. W.; Bishop, S. M.; Phillips, D.; J. Photochem. Photobiol. B 1991, 38, 10.

34. Hoshino, M.; Seki, H.; Shizuka, H.; J. Phys. Chem. 1985, 89, 470.

35. Pekkarinen, L.; Linschitz, H.; J. Am. Chem. Soc. 1960, 82, 2407.

36. Ohno, O.; Kaizu, Y.; Kobayashi, H.; J. Chem. Phys. 1985, 82, 1779.

37. Murov, S. L.; Carmichael, I.; Hug, G. L.; Handbook of Photochemistry, 2 $2^{\text {nd }}$ ed., Marcel Dekker: New York, 1993. 
38. Pinero, M.; Carvalho, A. L.; Pereira, M. M.; Gonsalves A. M. d'A. R.; Arnaut, L. G.; Formosinho, S. J.; Chem. Eur. J. 1998, 4, 2299.

39. Wilkinson, F.; Helman, W. P.; Ross, A. B.; J. Phys. Chem. Ref. Data 1993, 22, 113.

40. Zenkevich, E.; Sagun, E.; Knyukshto, V.; Shulga, A.; Mironov, A.; Efremova, O.; Bonnett, R.; Songca, P.; Kassen, M.; J. Photochem. Photobiol. B 1996, 33, 171.

41. http://www.photobiology.com/educational/len2/singox.html, accessed in August 2007.

42. Canete, M.; Villanueva, A.; Dominguez, V.; Pólo, S.; Juarranz, A.; Stockert, J.C.; Int. J. Oncol. 1998, 13, 497.

43. Lovcinsky, M.; Borecky, J.; Kubat, P.; Jezek, P.; Gen. Physiol. Biophys. 1999, 18, 107.

44. Faustino, M.A.F.; Neves, M. G. P. M.; Vicente, M. G. H.; Cavaleiro, J. A. S.; Neumann. M.; Brauer, H.-D.; Jori, G.; Photochem. Photobiol. 1997, 66, 405.

45. Faustino, M.A.F.; Neves, M. G. P. M.; Cavaleiro, J. A. S.; Neumann. M.; Brauer, H.-D.; Jori, G.; Photochem. Photobiol., 2000, 72, 217.

46. Pegaz, B.; Debefve, E.; Borle, F.; Ballini, J.-F.; van den Bergh, H.; Konan, Y. N. K.; J. Photochem. Photobiol. B, 2005, 80, 19.

47. Dzhagarov, B. M.; Gurinovich, G. P.; Novichenkov, V. E.; Salochiddinov, K. I.; Ganzha, V. A.; Khim. Fiz., 1987, 6, 1069.

48. Silvester, J. A.; Timmins, G. S.; Davies, M. J.; Free Radical Biol. Med. 1998, 24, 754.

49. Bonnet, R.; Rev. Contemp. Pharmacother. 1999, 10, 1.
50. Sternberg, D. E.; Dolphin, D.; Brükner, C.; Tetrahedron, 1998, $54,4151$.

51. Peters, T.; Adv. Protein Chem. 1985, 37, 161.

52. Lakowicz, J. R.; Principles of Fluorescence Spectroscopy; Plenum Press: New York, 1983.

53 Bose, B.; Dube, A,; J. Photochem. Photobiol. B 2006, 86, 49.

54. Hongwei, Z.; Min, G.; Zhaoxia, Z.; Wenfeng, W.; Guozhong, W.; Spectrochim. Acta A, 2006, 65, 811.

55. Chakrabarty, A.; Mallick, A.; Haldar, B.; Das, P.; Chattopadhyay N.; Biomacromolecules 2007, 8, 920.

56. Lambert, C. R.; Reddi, E.; Spikes, J. D.; Rodgers, M. A. J.; Jori, G.; Photochem. Photobiol. 1986, 44, 595.

57. Grossweiner, L. I.; Fernandez, J. M.; Bilgin, M. D.; Lasers Med. Sci. 1998, 13, 42.

58. Khalili, M.; Grossweiner, L. I.; J. Photochem. Photobiol. B 1997, 37, 236.

59. Ben-Hur, E.; Malik, Z.; Dubbelman, T. M. A. R.; Margaron, P.; Ali, H.; van Lier, J. E.; Photochem. Photobiol. 1993, 58, 351.

60. Davson, H.; Danielli, J. F.; The Permeability of Natural Membranes, $2^{\text {nd }}$ ed., Cambridge University Press: Cambridge, 1952.

61. Tran-Thi, T. H.; Lipskier, J. F.; Maillard, P.; Momentau, M.; Lopez-Castillo, J.-M.; Jay-Gerin, J.-P.; J. Phys. Chem. 1992, 96, 1073 .

Received: June 6, 2007

Web Release Date: March 5, 2008

FAPESP helped in meeting the publication costs of this article. 